\title{
National Action Plans on Business and Human Rights: an Experimentalist Governance Analysis
}

\author{
Claire Methven O'Brien ${ }^{1} \cdot$ John Ferguson ${ }^{2}$ (D) Marisa McVey ${ }^{2}$
}

Accepted: 19 August 2021 /Published online: 8 September 2021

(c) The Author(s) 2021

\begin{abstract}
National Action Plans (NAPs) on business and human rights are a growing phenomenon. Since 2011, 42 such plans have been adopted or are in-development worldwide. By comparison, only 39 general human rights action plans were published between 1993 and 2021. In parallel, NAPs have attracted growing scholarly interest. While some studies highlight their potential to advance national compliance with international norms, others criticise NAPs as cosmetic devices that states use to deflect attention from persisting abuses and needed regulation. In response to wider critiques of international human rights norms, and their failure to exact universal state compliance, experimentalist governance theory highlights the dynamic, dialogic and iterative character of human rights implementation as well as the role of stakeholders. In this article, we apply experimentalist governance theory to evaluate the role and character of business and human rights NAPs. Rather than attempting to evaluate NAPs' ultimate consequences for rights-holders, which appears premature, we focus on NAPs processes. Specifically, we analyse NAPs processes in twenty-five states against five experimentalist governance criteria relating to (i) stakeholder participation; (ii) agreement on a broad problem definition; (iii) local contextualisation; (iv) monitoring and peer review and (v) periodic revision and learning. According to our findings, NAPs on business and human rights in most states demonstrate resemblance to the traits of experimentalist governance. In particular, our analysis points to the emergence of relatively sophisticated and demanding institutional governance mechanisms within NAPs - including the institutionalisation of complex deliberative processes. Nevertheless, our paper also identifies some significant shortcomings in NAPs, related to the lack of inclusion of vulnerable groups and the lack of explicit indicators and targets.
\end{abstract}

Keywords National Action Plans (NAPs) - Business and human rights · Experimentalist governance · UN Guiding Principles on Business and Human Rights (UNGPs)

This paper is being submitted for consideration for the special issue on Business and Human Rights, edited by René Wolfsteller and Yingru Li.

Extended author information available on the last page of the article 


\section{Introduction}

National Action Plans (NAPs) on business and human rights are a growing phenomenon. ${ }^{1}$ Over the last ten years, 42 business and human rights NAPs have been published or are in-development worldwide. Fewer general human rights NAPs (39) were published over the forty-year period between 1993 and 2021. In parallel, NAPs have attracted growing scholarly interest (see, for example, De Felice and Graf, 2015; Methven O'Brien et al. 2016; Soh and Nam, 2018; Augenstein et al. 2018; Cantu Rivera, 2019; Hampton, 2019). While some studies highlight their potential to advance national compliance with international norms, others criticise NAPs as cosmetic devices that states use to deflect attention from persisting abuses and needed regulation.

Pronouncing on the consequences of business and human rights NAPs for rightsholders or their ultimate effectiveness as drivers of regulatory change seems premature. On the other hand, the character of NAPs processes can still be meaningfully assessed. Building on earlier work (Ferguson et al. 2018; Methven O'Brien et al. 2016), as well as insights from practice, ${ }^{2}$ this article makes a novel contribution to scholarly discussion of business and human rights NAPs by evaluating NAPs processes from the perspective of experimentalist human rights governance (de Búrca et al., 2014; de Búrca 2017).

Twentieth century critics of international human rights norms have questioned their effectiveness and legitimacy (Hathaway 2002, Neumayer 2005, Goldsmith and Posner 2005, Hathaway 2007, Moyn 2012, Posner 2014). Experimentalist human rights governance theory embodies one response to such critiques. This suggests a revised understanding of the mechanisms by which international human rights norms take effect within and beyond states. According to experimentalist tenets, implementation of international human rights norms is not a top-down, linear process of transposing specific rules to national contexts on a one-off basis. Rather, like certain other efforts to address complex transnational collective problems, human rights implementation is a dynamic, iterative and an "institutionalised process of participatory and multi-level collective problem-solving" (de Búrca et al., 2014, p.477) which relies essentially on "cooperation between different actors and learning as a way to support accountability and transparency" (Armeni 2015, p.882; see also de Búrca 2010; de Búrca et al. 2013; Goldstein and Ansell 2018). Another key feature of experimentalist governance is subordinate processes which apply discretion, informed by deliberation and local data, to devise programmes aligned with the goals of the international norms in question.

Besides being a sub-field of human rights, the experimentalist lens appears appropriate to business and human rights for other reasons. As argued elsewhere (Methven O'Brien and Ford 2019), business and human rights problems, in terms of abuses and implementation gaps, are endemic across economies; root causes are

\footnotetext{
1 A business and human rights NAP is an "evolving policy strategy developed by a State to protect against adverse human rights impacts by business enterprises in conformity with the [United Nations Guiding Principles on Busines and Human Rights]" (UNWG 2012).

${ }^{2}$ Footnote removed to preserve anonymity.
} 
multiple and hard to diagnose; value conflicts are pervasive; and solutions, if they are to be had, imply the pooling of knowledge, resources and sustained multi-actor cooperation (Methven O'Brien 2019; see also Kenner and Peake 2017). Accordingly, business and human rights carries a likelihood of value conflicts across states, local policy variation and a need to evaluate effectiveness over time, rather than against a prior universal template.

On this basis, and advancing a line of inquiry embarked on by scholars in other policy fields (e.g. Goldstein and Ansell; Kenner and Peake, DeBurca), we consider it relevant to investigate whether business and human rights NAPs processes function in line with experimentalist governance theory. If such NAPs do already, or demonstrate potential in the future, to function as elements of an experimentalist business and human rights governance architecture, this might lend further weight to experimentalist and specifically experimentalist human rights governance theory. In addition, it might add strength to arguments favouring a framework convention approach to an international business and human rights treaty (Methven O'Brien 2019). On the other hand, if business and human rights NAPs lack the role or qualities required by experimentalist governance theory, it may be asked, whether they could do so, and if so, under what conditions. Alternatively, it might follow that other approaches to international standard-setting and national implementation of international business and human rights norms should be pursued instead.

This article is structured as follows. Section 2 introduces experimentalist governance theory and experimentalist human rights theory. Section 3 describes the antecedents to business and human rights NAPs, as well as the range of policies and measures that have, since 2011, been adopted to promote them. Section 4 considers guidance from human rights bodies on how business and human rights NAPs should be developed and what they should contain. This section further shows how the main recommendations contained in NAPs guidance map to the main characteristics of experimentalist governance outlined by its proponents. In Sect. 5, we evaluate existing business and human rights NAPs against these criteria. Section 6 discusses the significance of our findings and Sect. 7 concludes, highlighting questions for future research.

\section{Experimentalist Governance: Context and Concept}

Scholarship in political science, international relations, sociology and law upholds a difference between "government" and "governance", as two paradigms of regulation and public administration. ${ }^{3}$ Government, in this sense, connotes efforts by the state to achieve its aims through hierarchy, the exercise of formal authority, and "command and control", for instance, via detailed legislative schemes backed by statutory enforcement agencies and powers (Braithwaite and Drahos 2000; Guy Peters 2011).

\footnotetext{
3 By regulation we refer, with Black (2008, p.139), to "sustained and focused attempts to change the behaviour of others in order to address a collective problem or attain an identified end or ends, usually through a combination of rules or norms and some means for their implementation and enforcement, which can be legal or non-legal.".
} 
Preconditions of the effectiveness of "government" on this account include a single legislative centre and unitary bureaucracy enjoying accurate knowledge of societal conditions; social uniformity; a high level of social (and market) compliance with enacted rules; and adequate resources to support centralised oversight and enforcement mechanisms.

During the era of the modern state, this concept of "government" was historically prevalent. In the later twentieth century, however, some of its prerequisites appeared to weaken.Sociologists and socio-legal scholars highlighted the relative autonomy of society from direct government intervention (see, for example, Teubner, 1983; 1997). Besides, during the 1970s and 1980s, market mechanisms found political favour while national and international actors attributed economic problems to overreliance on, or intrinsic failures of, centralised government planning (Chimhowu et al. 2019, p.79; World Bank 1983). At the same time, new transnational environmental, security and technological challenges triggered the rise of supranational institutions. Authority was observed to have dispersed "upwards to the supranational level, downwards to subnational jurisdictions, and sideways to public/private networks" (Hooghe and Marks 2001, p.4). Given the limited mandates and resources of international institutions, this encouraged, amongst others, the growth of public-private partnerships, while international organisations "increasingly orchestrated new forms of authority involving non-state actors" (de Búrca et al. 2013, p.734-735), for instance, via policy networks. ${ }^{4}$

In this context, governance emerged as a "research agenda on order and disorder, efficiency and legitimacy all in the context of the hybridization of modes of control that allow the production of fragmented and multi-dimensional order within the state, by the state, without the state, and beyond the state" (Levi-Faur, 2012). Often found in domains governed by soft law, governance was observed to involve "actors other than classically governmental actors, or indeed the absence of any traditional framework of government" and "approaches which are less rigid, less prescriptive, less committed to uniform outcomes, and less hierarchical in nature" than conventional regulation (de Búrca and Scott 2006, p.2).

"New governance" was coined as an umbrella term denoting "a range of processes and practices" identified by researchers "that have a normative dimension but do not operate primarily or at all through the formal mechanism of traditional command and control type legal institutions" (de Búrca and Scott 2006, p.2). Across policy domains, new governance regimes were found to emphasise the "accommodation and promotion of diversity... the importance of provisionality and revisability - in terms of both problem definition and anticipated solutions - and... the goal of policy learning" (de Búrca and Scott 2006, p.3). New governance arrangements incorporated "states, sub-state units, international organizations, civil society organizations, private actors, and others" in arrangements lacking formal hierarchy

\footnotetext{
4 As Slaughter observed in 1997: "The state...is disaggregating into its separate, functionally distinct parts. These parts-courts, regulatory agencies, executives, and even legislatures are networking with their counterparts abroad, creating a dense web of relations that constitutes a new, transgovernmental order" (1997, p.184).
} 
(de Búrca et al. 2013, p.726, see also, Keohane and Victor 2011; Ruggie 2002). In the specific setting of the European Union, the "Open Method of Coordination" (OMC) sought to drive coordination and convergence across the EU's member states towards commonly agreed goals, in areas where binding laws were lacking, via peer exchange, dialogue and review, reporting against standardised metrics as a basis of benchmarking to promote their achievement, and National Action Plans (NAPs) (Panke and Haubrich-Seco 2016).

These developments triggered reflection on the legitimacy of such mechanisms for achieving public goals or implementation of legal norms, given that they could not lay claim to be representative or enjoy delegated authority in conventional terms. Ideals of deliberative rationality here entered into play (Fung and Wright 2003, p.4). ${ }^{5}$ Likewise, new governance entailed accountability challenges (Black 2002; Bovens 2006; Sabel and Simon 2006; Black 2008) and a need to reflect on the concept of law itself, stimulating interest in legal pluralism (De Sousa Santos 1995; Teubner 1997; see generally Berman 2020).

Experimentalist governance theory took shape against this background (de Búrca and Scott 2006). Experimentalist governance, scholars suggested, could be identified in policy areas characterised by persistent uncertainty or value conflicts, where governments or other parties could agree on a broad problem definition but lacked the know-how or agreement necessary to isolate specific solutions (Búrca et al. 2013, p.740). ${ }^{6}$ Experimentalist governance regimes "set provisional goals" rather than fixed rules. In response to social complexity (Nance and Cottrell, 2014) or where the issue at hand is characterised by "insufficient information and uncertainty" (BarSiman-Tov, 2016, p.193; see also, Sabel and Zeitlin 2012), experimentalist regimes institutionalise stakeholder participation and processes for revision. ${ }^{7}$ This approach according to scholars produces greater learning, adaptation and reliability over time (Sabel and Simon 2011, p.55).

Experimentalist human rights governance was advanced in response to recent critiques of international human rights norms that questioned their effectiveness and legitimacy (Hathaway 2002, Neumayer 2005, Goldsmith and Posner 2005, Hathaway 2007, Moyn 2012, Posner 2014). For example, in her analysis of the human rights treaty system, de Búrca $\left(2017\right.$, p.279) ${ }^{8}$ argues that the "iterative interaction between civil society actors, UN treaty bodies, and governmental actors", transforms

\footnotetext{
5 Amongst US-based scholars, many accounts referred back to pragmatism and Dewey's "democratic experimentalism" (Dewey 1927; Dorf and Sabel 1998) while in Europe, connections were explored to the work of Habermas and Luhmann, amongst others (e.g. Teubner 1983; Joerges and Neyer 2006).

${ }^{6}$ For example, the EU and the Open Method of Coordination (Sabel and Zeitlin 2008; Zeitlin 2011); HIV/AIDS (Goldstein and Ansell 2018); Bangladesh Sustainability Compact (Kenner and Peake 2017); climate change technologies (Armeni 2015). Sabel and Simon (2011) focus on exepimentalism in "management-based regulation" schemes in the areas of environmental, health, mining and nuclear and safety (p.83) and social welfare (pp.89-93).

7 This distinguishes experimentalist governance from regime complexes and distributed networks which still tend to "fix precise, binding, and definitive rules to give effect to their policy preferences": de Búrca et al., 2013p.743.

${ }^{8}$ de Búrca (2017) examines three of the UN human rights treaty systems-the CEDAW, CRC, and CRPD.
} 
the human rights treaty process "into [a] more participatory and accountable experimentalist governance system[]" (p.310). According to de Búrca $(2017,279)$, not only does an experimentalist governance account better reflect the actual operation of the treaty regime, the interaction between key actors, especially when associated with an "active domestic civil society", tends to be associated with positive domestic human rights outcomes.

In their 2013 account, de Búrca et al (2013, p.723) identify five key features of experimentalist governance ${ }^{9}$ :

1.Openness to participation of 'stakeholders' who must share at least a broad perception of a common problem in a non-hierarchical process ${ }^{10}$;

2.Articulation of a framework definition of a problem or goals which identifies open-ended objectives to be pursued;

3.Implementation is "left to 'lower-level' actors with knowledge of local conditions and considerable discretion to adapt the framework norms to these different contexts" (de Búrca et al. 2014, p.478; de Búrca et al. 2013, p.739; Sabel and Simon 2011, p.55);

4.Continuous feedback from local actors incorporating "mutual monitoring and peer review, involving elaborate processes of consultation that are horizontal rather than vertical in structure", serving an accountability function (de Búrca et al. 2013, p.742);

5.Revision and re-evaluation: goals and practices are "periodically and routinely re-evaluated and, where appropriate, revised in light of the results of the peer review and the shared purposes" (de Búrca et al. 2014, p.478).

Experimentalist governance, then, is a theory derived from institutional observation by social scientists. Yet, it is also viewed by its socio-legal scholar exponents as "normatively attractive" (de Búrca 2017, p.281) insofar as it is claimed to encourage "participatory, deliberative, locally-informed, and adaptive problem solving" (de Búrca et al. 2014, p.480; see also Armeni 2015, p.876) while being able to address contemporary transnational challenges in ways that state-based actors and "traditional" governmental processes, for a variety of reasons as alluded to above, cannot (de Búrca et al. 2014; de Búrca et al. 2013, p.727; Methven O’Brien 2019, p.204).

On the above basis, we suggest, an experimentalist governance analysis of business and human rights NAPs is relevant while also making a novel scholarly contribution. First, the implementation via NAPs of international soft law standards on business and human rights, namely the UNGPs, represents a further empirical

\footnotetext{
9 Although all five of these features must be present in order for a governance system to be considered experimentalist, de Búrca (2010, p.235) notes:"[T]he two most crucial features of an experimentalistgovernance system, and those without which the system will fail in addressing the problem, are (1) the broadest possible degree of stakeholder participation compatible with effective decision-making, and (2) effective and informed monitoring"; see also de Búrca et al. 2013, p.726, 2014).

10 The absence of hierarchy is defined here in a notably modest way: according to Goldstein and Ansell (p.230-231), "While the [experimentalist] model envisions a central unit, this unit is not a hegemon imposing its will.".
} 
setting for testing experimentalist governance theory and experimentalist human rights theory specifically, advancing a line of inquiry embarked on by others (cf. Nance and Cottrell, 2014, p.284; Kenner and Peake, 2017; Goldstein and Ansell, 2018; de Burca, 2017). Second, it may illuminate whether the national implementation of business and human rights norms mirrors or diverges from that of other human rights standards. Third, it may shed light on the ongoing debate over how an international business and human treaty should be designed, in terms of substantive content, institutionalisation, oversight and accountability mechanisms. Last but not least, though it is not yet timely to draw final conclusions on the efficacy of NAPs as drivers for regulatory change, business behaviour, or the effectiveness of enjoyment of human rights for individuals and groups in the market sphere, evaluating NAPs processes in terms of experimentalist governance may yield tentative indications of what to expect in these areas in future. It may also help to better qualify understanding of the reasons for ready pursuit of business and human rights NAPs by states and others, while also guiding reflection about what may be expected to result from this trend in the years ahead.

\section{Business and Human Rights NAPs: Antecedents and Current Practice}

In this section, we provide an outline of the emergence of NAPs in the area of human rights before providing an overview of the current state of play with regard to business and human rights NAPs. In Sect. 4, we then consider the extant guidance on the development of business and human rights NAPs in order to more explicitly consider how such guidance tracks against the experimentalist governance criteria outlined above.

\section{National Action Plans on Human Rights}

Since the 1980s, intergovernmental bodies have encouraged the adoption of NAPs as a device to advance states' fulfilment of international obligations and policy commitments. This approach has been applied across domains including "greening public procurement" (European Commission 2020), public health (Tuangratananon et al. 2019), tobacco control, gender equality (PeaceWomen 2020), anti-corruption and human trafficking (ICMPD 2006), climate change, biodiversity, corporate social responsibility as well as human rights.

Regarding the latter, the first textual reference to the adoption of national action plans can be traced to provisions of the 1966 International Covenant on Economic, Social and Cultural Rights (ICESCR) (Chalabi 2014, p.391; see also Chalabi 2018a; 2018b). Later, the Vienna Declaration and Programme of Action urged states to "consider...drawing up a national action plan identifying steps whereby that State would improve the promotion and protection of human rights" (UN OHCHR 1993, p.17; Chalabi 2014). To date, 39 countries have developed such plans, often with support from international agencies, such as the UN Office of the High 
Commissioner of Human Rights or UN Development Programme, and linked to post-conflict or democratic transition. ${ }^{11}$

Subsequently, the use of NAPs to advance implementation of the UN Convention on the Rights of the Child (European Union Agency for Fundamental Rights 2014) and UN Convention on the Rights of Persons with Disabilities (Lorion, 2019) has been advocated. States have regularly been recommended to develop NAPs by UN treaty monitoring bodies, such as the Committee on the Elimination of Racial Discrimination (Chalabi 2014).

Neither the UN Human Rights Council 2008 Framework, UNGPs UN Human Rights Council 2011 on business and human rights nor associated UN Human Rights Council resolutions identify specific mechanisms for national implementation, whether NAPs or alternatives such as focal points or government coordination mechanisms. ${ }^{12}$ The mandate of the UN Working Group on Business and Human Rights established by UN HRC Res 17/4 embraces the promotion of the UNGPs at national level but does not advert to any national processes or structures in particular (UN HRC 2011).

Nonetheless, the idea of business and human rights-specific NAPs quickly grew in prominence. Their first mention in a formal policy appeared in the European Commission's 2011 White Paper on Corporate Social Responsibility. This invited Member States "to develop ... national plans for the implementation of the UN Guiding Principles" (European Commission 2011, p.13-14), reflecting the EU's reliance on NAPs in other policy areas as a mechanism to promote convergence across member states where legal obligations were lacking, as mentioned above.

The European Council's 'Strategic Framework on Human Rights and Democracy' (Council of the European Union 2012; Council of the European Union 2015) reiterated a call to states to develop business and human rights NAPs, as did later Council-focused recommendations (e.g. Dutch Government 2016; Finnish Government 2019; German Ministry of Labour and Social Affairs 2020); and Conclusions on Human Rights and Decent Work in Global Supply Chains (Council of the European Union 2020). Beyond the EU, NAPs have been recommended by the UN Human Rights Council (UN Human Rights Council 2014), Council of Europe (COE 2014) and Organization of American States (2014, 2016), while the OECD recommended its NAPs as a tool to advance "responsible business conduct" (OECD 2017).

Human rights actors also engaged in advocacy and the production of guidance on business and human rights NAPs. Recommendations by the European Network of National Human Rights Institutions (ENNHRI) urged the need for a "human rightsbased approach" (UN 2003) encompassing inclusion, transparency, participation and accountability in NAPs processes (ENNHRI 2012, 2020). A UN special mandate, the Working Group on Business and Human Rights, issued NAP guidance along similar lines (UN Working Group 2012). Following wide-ranging consultations, the

\footnotetext{
11 See e.g. https://www.ohchr.org/en/issues/plansactions/pages/plansofactionindex.aspx and OHCHR, Handbook on National Human Rights Plans of Action (2002), available at: https://www.ohchr.org/ Documents/Publications/training10en.pdf

12 Such elements are referred to under UNCPRD Article 33, for example.
} 
Danish Institute for Human Rights (DIHR) and International Corporate Accountability Roundtable (ICAR) published a 'Toolkit' on business and human rights NAPs (DIHR/ICAR 2014; 2017). DIHR and ICAR then collaborated with other organisations to produce NAPs guidance addressing specific sectors, themes or categories of rights-holders, such as children's rights (DIHR, ICAR and UNICEF 2016); the extractive sector (Due Process of Law Foundation and ICAR 2017); the tech sector (DIHR and Global Partners Digital 2020) and private security (DCAF and DIHR 2020a, b).

\section{Business and Human Rights NAPs: Current Practice}

By the end of 2020, twenty-five states had published business and human rights NAPs (DIHR 2020a, b). Nineteen of these came from Council of Europe states and fifteen from EU member states. Asian states account for three; Latin America for two; and the USA the last (Table 1). While adoption of NAPs across world regions is hence uneven, regional differences could diminish in future: of seventeen states developing business and human rights NAPs the Americas and Asia each account for five, Africa for four and Europe three (Table 2). Also at end 2021, four states were producing revised, updated or second business and human rights NAPs (DIHR 2020a, b). A few states have been prompted to develop NAPs by recommendations received through the UN Universal Periodic Review (UPR) process (ibid.). ${ }^{13}$ An overall total of fortytwo published and in-development business and human rights NAPs compares with thirty-nine general human rights NAPs produced since1993 (OHCHR 2020).

*Business and human rights chapter within broader human rights NAP.

\section{Guidance on Business and Human Rights NAPs}

Two guidance documents on business and human rights NAPs have been widely relied on by government and other actors in the NAPs processes just enumerated. These are the DIHR-ICAR Toolkit $(2017,2011)$ and UNWG NAPs guidance (UNWG 2014, 2016). This section considers how far these documents' recommendations map to the character and role of local implementation hypothesised by experimentalist governance theory; in doing so, this section highlights the considerable degree of overlap between NAP guidance the experimentalist governance criteria outlined above.

Both the DIHR-ICAR Toolkit and UNWG NAPs guidance envisage an iterative cycle: the five steps in the diagram extracted from the Toolkit (DIHR/ICAR 2017) also constitute the "essential" phases flagged by the UNWG NAPs guidance (2014, 2016, p.ii) (Fig. 1).

Both guides first emphasise the role of stakeholder involvement throughout a NAP process. This requires "stakeholder mapping" exercise, establishing a multi-stakeholder advisory or working group and steps to secure participation of marginalised or

13 For example, Kenya and Honduras. 
Table 1 States with published business and human rights NAPs

\begin{tabular}{|c|c|c|}
\hline Country & Year published & Period covered by NAP \\
\hline Belgium & 2017 & Open ended \\
\hline Chile & 2017 & August 2017-2019 \\
\hline Colombia & 2015 & Dec 2015-Dec 2018 \\
\hline Czechia & 2017 & Oct 2017-2022 \\
\hline Denmark & 2014 & Open ended \\
\hline Finland & 2014 & Open ended \\
\hline France & 2017 & Open ended \\
\hline Georgia* & 2018 & March 2018-2020 \\
\hline Germany & 2016 & December 2016-2020 \\
\hline Ireland & 2017 & November 2017-2020 \\
\hline Italy & 2016; updated 2018 & December 2016-2021 \\
\hline Japan & 2020 & October 2020-2025 \\
\hline Lithuania & 2015 & Open ended \\
\hline Luxembourg & 2018; updated 2020 & June 2020-2022 \\
\hline Netherlands & 2013 & Open ended \\
\hline Norway & 2015 & Open ended \\
\hline Poland & 2017 & May 2017-2020 \\
\hline Slovenia & 2018 & Open ended \\
\hline South Korea* & 2019 & Open ended \\
\hline Spain & 2017 & July 2017-July 2020 \\
\hline Sweden & 2015 & Open ended \\
\hline Switzerland & 2016; updated 2020 & 2020-2023 \\
\hline Thailand & 2019 & 2019-2022 \\
\hline United Kingdom & 2013; updated 2016 & Open ended \\
\hline United States of America & 2016 & Open ended \\
\hline
\end{tabular}

at-risk groups (DIHR/ICAR Toolkit 2017, p.20-23). In addition, it entails a need for transparency: information about "key milestones in the NAP process and participation opportunities such as dialogues, workshops, consultation events, and comment periods" should be readily available (see also UNWG, 2014, p. 14).

Likewise, concerning the scope, content and priorities of a NAP, both documents highlight the need for alignment to the UNGPs. To this end, they share the view that a baseline assessment should be undertaken "to inform the formulation and prioritisation of actions in a NAP" (DIHR/ICAR, 2017 p.25; cf ENNHRI) and as a datum to inform stakeholders in the context of consultations. A baseline assessment should also promote a NAP's context-specificity, a key criterion for the UNWG.

Turning to implementation, monitoring, and review, the DIHR/ICAR Toolkit (2017, p.36) asserts that:

"Publishing a NAP is not the end of the process, but rather the beginning of the implementation phase. Incorporating an implementation plan, monitoring and review mechanisms, and reporting mechanisms into a NAP 
Table 2 States currently developing business and human rights NAPs

\begin{tabular}{ll}
\hline Country & Date commitment/process announced \\
\hline Argentina & December 2017 (commitment in NAP on Human Rights) \\
Ecuador & October $15^{\text {th }}, 2020$ (government announcement) \\
Honduras & November, 2018 (government announcement) \\
India & November, 2018 (government announcement) \\
Indonesia & June $19^{\text {th }}, 2015$ (NHRI announced process of drafting NAP) \\
Kenya & February $9^{\text {th }}, 2016$ (process launched by Attorney General) \\
Liberia & July, 2018 (government commitment) \\
Malaysia & March $24^{\text {th }}, 2015$ (government commitment) \\
Mexico & December, 2015 (launched during the UN Annual Forum on Business \\
Mongolia & and Human Rights) \\
Morocco & April, 2019 (government appointed working group) \\
Pakistan & Not clear* \\
Peru & October $17^{\text {th }}, 2019$ (Ministry of Human Rights initiated process) \\
Portugal & September $27^{\text {th }}, 2018$ (commitment in NAP on Human Rights) \\
Scotland & No information in English \\
Uganda & December $10^{\text {th }}, 2013$ (commitment in NAP on Human Rights) \\
Ukraine & 2016 (Accepted UPR recommendation) \\
\hline & January, 2019 (Ministry of Justice announced commencement of process) \\
\hline
\end{tabular}

increases the likelihood that the commitments made in the NAP will be implemented in practice" (p.36).

Implementation and effective monitoring are thus regarded as closely linked. They are also said to require that a NAP's objectives are specific, measurable, achievable, relevant and time-specific (SMART) and, besides government-led progress reviews, the undertaking of independent and peer-reviews, and monitoring at national, regional and international levels. Stakeholder monitoring arrangements should include "state institutions, business, and civil society" (DIHR/ICAR (2017 p.37).

Finally, both guidances urge NAPs' periodic revision and renewal. The UNWG includes review, monitoring and regular updating as one of its five essential NAP criteria (UN Working Group on Business and Human Rights 2014, 2015, UN Working Group on Business and Human Rights 2016). According to the Toolkit,

"Incorporating a commitment to update a NAP allows the lessons learnt during creation, implementation, and review to be put into practice and demonstrates a commitment to progressively realise the "protect, respect, remedy" framework of the UNGPs" (DIHR/ICAR 2017, p.47).

Table 3 maps the elements of NAPs guidance as mentioned against de Búrca et al.'s $(2013,2014)$ features of experimentalist governance, namely openness to participation of 'stakeholders' in a non-hierarchical process (EG1); articulation of a broadly agreed common problem (EG2); implementation by lower-level actors with 


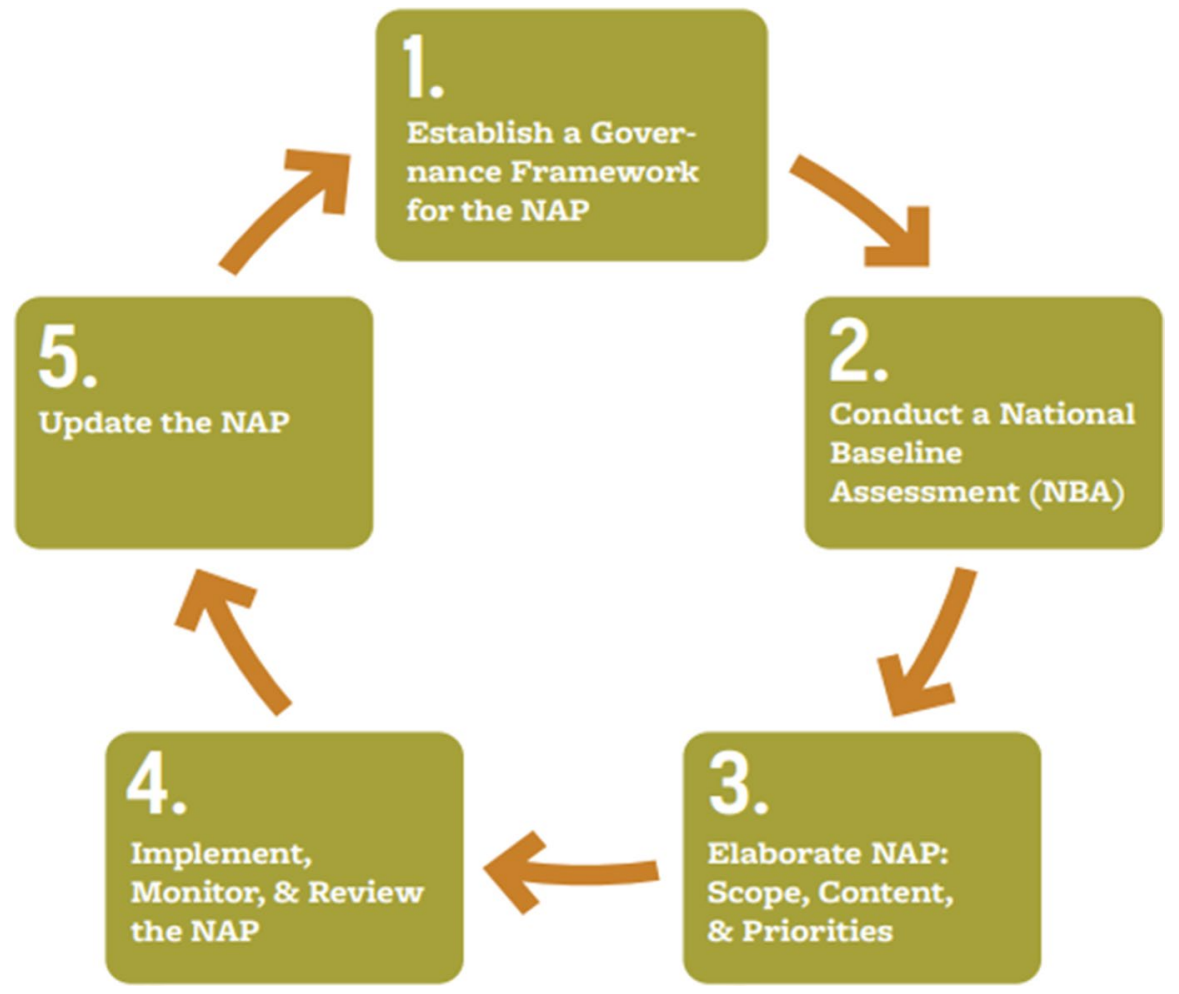

Fig. 1 Diagram extracted from the Toolkit (DIHR/ICAR 2017) constituting the "essential" phases flagged by the UNWG NAPs guidance

local knowledge and contextualisation (EG3); continuous feedback, reporting, and monitoring (EG4); and revision and re-evaluation involving peer review (EG5).

This shows how the attributes of experimentalist governance, on one hand, and the recommendations advanced by the NAP guidance documents considered above, on the other, overlap. Given this, if actual NAPs processes undertaken by states and stakeholders align with NAPs guidance, they too may have attributes that are characteristic of, or which could contribute to, experimentalist governance.

Vice versa, if NAPs practice across states does not follow NAPs guidance, this is also potentially informative. If divergences between NAPs guidance and actual NAPs processes are observed uniformly across all states this might be because, for instance, experimentalist governance is essentially less likely in the area of business and human rights than in other policy domains or areas of human rights (de Búrca 2017; Armeni 2015; Kenner and Peake 2017; Goldstein and Ansell 2018), for instance, due to greater and universal power differentials between key players (Birchall 2021). Or, if traits of experimentalist governance are observed in some, but not other states' business and human rights NAPs, this might trigger a search for contingent, rather than structural, factors to explain this. 


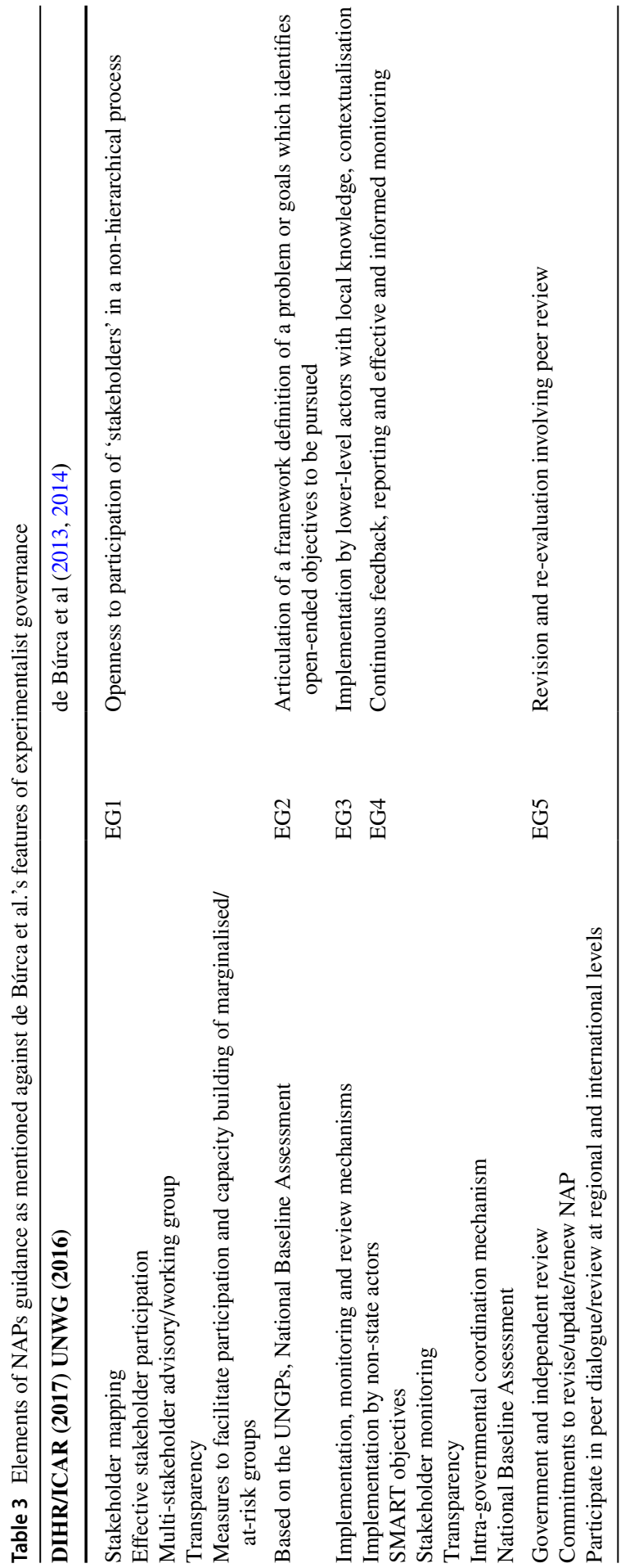




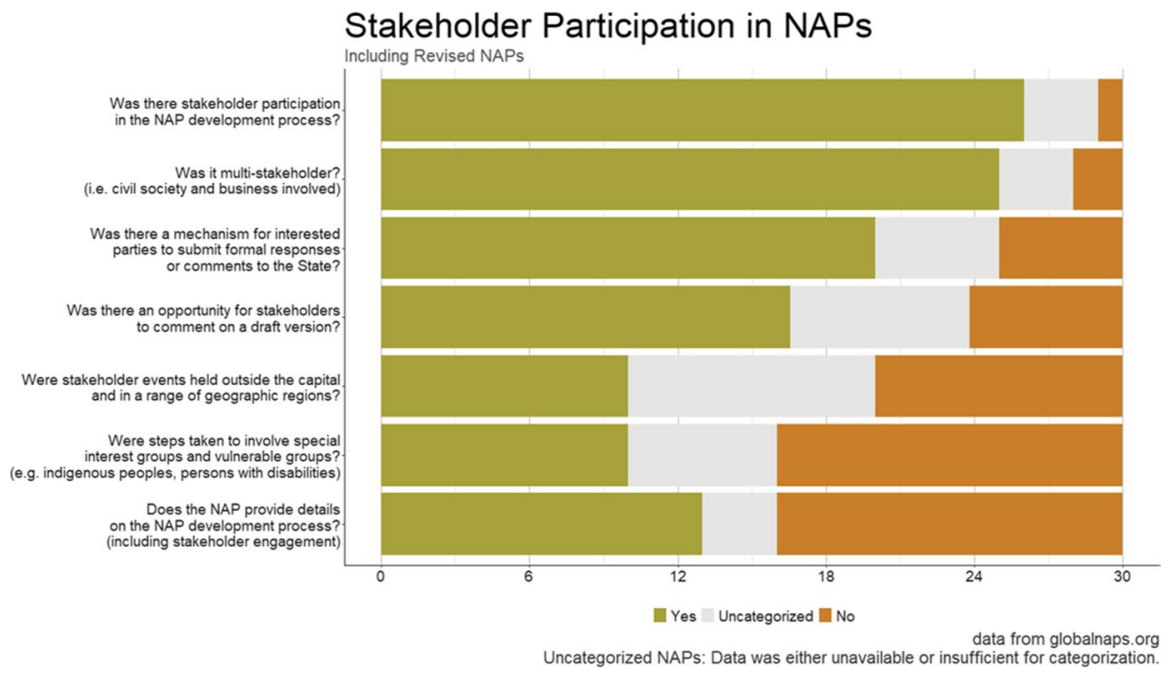

Fig. 2 Stakeholder participation in NAPs

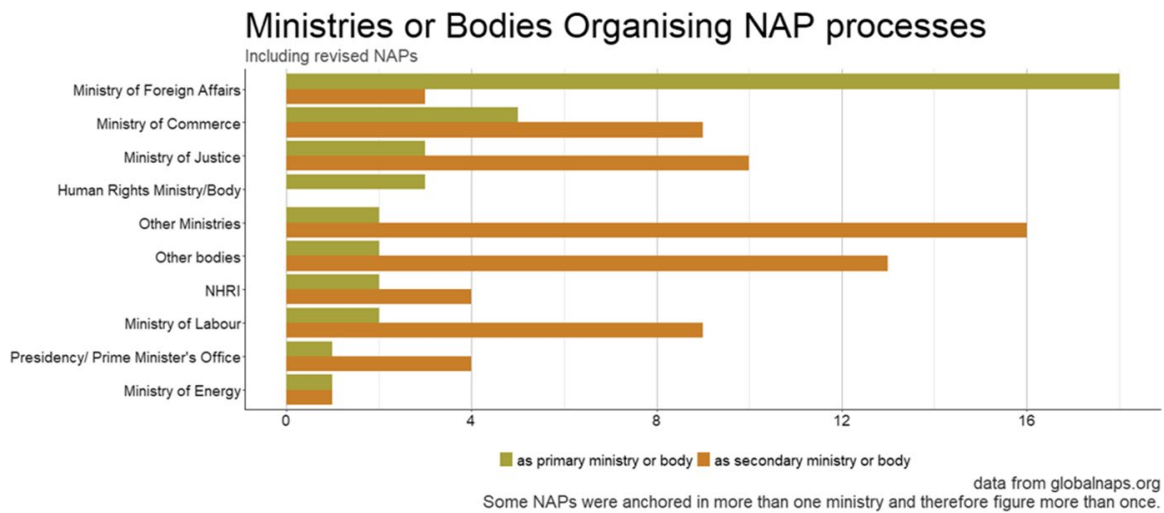

Fig. 3 Ministries or bodies organising NAP processes

\section{Preliminary Analysis of NAPs Against Experimentalist Governance Criteria}

Twenty-five states have concluded business and human rights NAPs processes. The www.globalnaps.org (2020) website presents, for each published NAP, a breakdown of its content into different topics and themes, for example, children's rights, corruption, forced labour and modern slavery. In addition, www.globalnaps.org presents for each NAP various materials describing or relating to its production, such as reports from stakeholder meetings, baseline assessments, inputs and commentaries from NGOs, business associations and other actors. For this article, we reviewed the www. globalnaps.org data on the twenty-five published NAPs; the texts of those NAPs; and 
other external sources and commentaries. Next, we present our initial qualitative analysis of these materials according to the following categories, derived from Table 3: (i) stakeholder participation; (ii) agreement on common problem; (iii) implementation, monitoring and reporting, and; (iv) revision and re-evaluation involving peer review.

\section{Stakeholder Participation in NAP Processes}

Stakeholders participated in the production of NAPs in all of the twenty-five states that published a NAP (Fig. 2).

As these data show, the extent and modalities of stakeholder engagement varied widely across states, however. Mechanisms to facilitate stakeholder involvement included national multi-stakeholder conferences on business and human rights (for example, Chile and Colombia); stakeholder dialogues for specific sub-national regions (for example, Colombia, Italy, Sweden); separate workshops for business and civil society (for example, Chile, Finland, France, Georgia, Germany, Ireland, Italy, Japan, Luxembourg, Norway, Slovenia, and the UK); questionnaires or interviews (for example, Belgium, Netherlands, Switzerland; public consultations or written submissions (for example, Belgium, Chile, Finland, Ireland, Italy, Poland, Slovenia; Switzerland, Thailand, the UK); and establishment of a multi-stakeholder steering group (for example, Colombia, Czechia, Germany and Switzerland).

In Colombia, Czechia, Germany and Switzerland, a multi-stakeholder steering group was given the actual task of developing the NAP. Germany's NAP Steering Committee, for instance, comprised representatives of six government ministries (Fig. 3), trade associations, Germany's national human rights institution, a trade union representative and one civil society representative. ${ }^{14}$ Besides, in Germany, over 100 stakeholders attended an opening conference at which they provided inputs from which ten priorities to be addressed by the NAP were extracted. In addition, a sequence of expert hearings were organised jointly,

"by organizations from different stakeholder groups (government, trade unions, business, civil society). NGOs, including Amnesty International and Oxfam, were [also] nominated... Each stakeholder group selected 10 experts who represented them and their approaches during the meeting..."15

In the Netherlands, by contrast, a consultant was engaged on behalf of the government who conducted " 27 interviews with more than 50 people representing the main stakeholder groups (business, civil society and implementing organisations) during the pre-drafting phase, as well as a round of single stakeholder consultations during the drafting process". ${ }^{16}$ In France, twelve stakeholder groups were consulted, while input to the NAP was provided by France's national "CSR Platform". In Belgium, stakeholders were invited to "submit ideas and propositions on relevant actions" in the initial stages. ${ }^{17}$

\footnotetext{
14 See: https://globalnaps.org/country/germany/

15 See: https://globalnaps.org/country/germany/

16 See: https://globalnaps.org/country/netherlands/.

17 See: https://globalnaps.org/country/belgium/.
} 
In terms of categories of stakeholder participating in NAPs processed embraced: national and local government departments and agencies; national human rights institutions (NHRIs); civil society organisations (CSOs); businesses (individual businesses and umbrella organisations); labour and trade unions; international agencies; academics; and specific groups of rights-holders. All but two NAPs processes (Lithuania and South Korea) involved both business and civil society participants. However, only in nine states were steps taken to involve groups at heightened risk of vulnerability or marginalisation, such as indigenous peoples or persons with disabilities. ${ }^{18}$ In addition, NAPs have generally not entailed or been preceded by actual stakeholder mapping exercises to identify relevant constituencies. Indeed, only nine NAPs processes took steps to integrate vulnerable groups. As a result, across business and human rights NAPs processes,

“older persons, children, LGBTI, persons with disabilities, women, representatives of indigenous communities, the self-employed, and small and mediumsized businesses -[have] not been adequately included" (Ferguson et al. 2018).

Most NAPs also provide for stakeholder engagement in follow-up and review mechanisms, discussed further below.

\section{Agreement on Framework Definition of a Common Problem}

Business and human rights NAPs and NAPs processes appear to embody a broad problem definition shared across states and stakeholders. All published NAPs are explicitly linked to the UNGPs with the majority loosely structured according to the three pillars of the UN Framework (Morris et al. 2018). All NAPs also express a government commitment to implement the UNGPs.

Guidance suggests that NAPs should systematically reflect on each of the UNGPs and its relevance in the national context in question (ENNHRI 2012, p.5). Yet only two states' NAPs (Italy and Spain) are structured to address each UNGP individually (see Fig. 4). A National Baseline Assessment (NBA) to audit gaps in national UNGPs implementation and identify "the most salient human rights issues in a given context" (DIHR/ICAR 2017, p.25) can be one mechanism by which such analysis can be undertaken.

To date, NBAs have been undertaken by eleven of the twenty-five states with NAPs. In seven of these, the NBA was completed before the NAP, while in four states, publication of the NBA followed the NAP. ${ }^{19}$ Of the seven NBAs completed beforehand, five were produced by external organisations on behalf of the state; and two by the state and other organisations jointly. Germany's NBA was developed by the German Institute for Human Rights and involved three rounds of consultations with stakeholders from government, trade unions, business and civil society. ${ }^{20}$ The content of Germany's NBA drew on these consultations and the NBA, officially

\footnotetext{
18 Chile, Colombia, Denmark, Georgia, Germany, Italy, Spain, Switzerland, Thailand.

19 Countries that have developed NBAs: Chile, Czechia, Georgia, Germany, Italy, Norway, Thailand. Ireland, Luxembourg, Switzerland ( $\left.2^{\text {nd }} \mathrm{draft}\right)$ and the Netherlands conducted NBAs following publication of their initial NAPs.

20 See: https://globalnaps.org/country/germany/.
} 


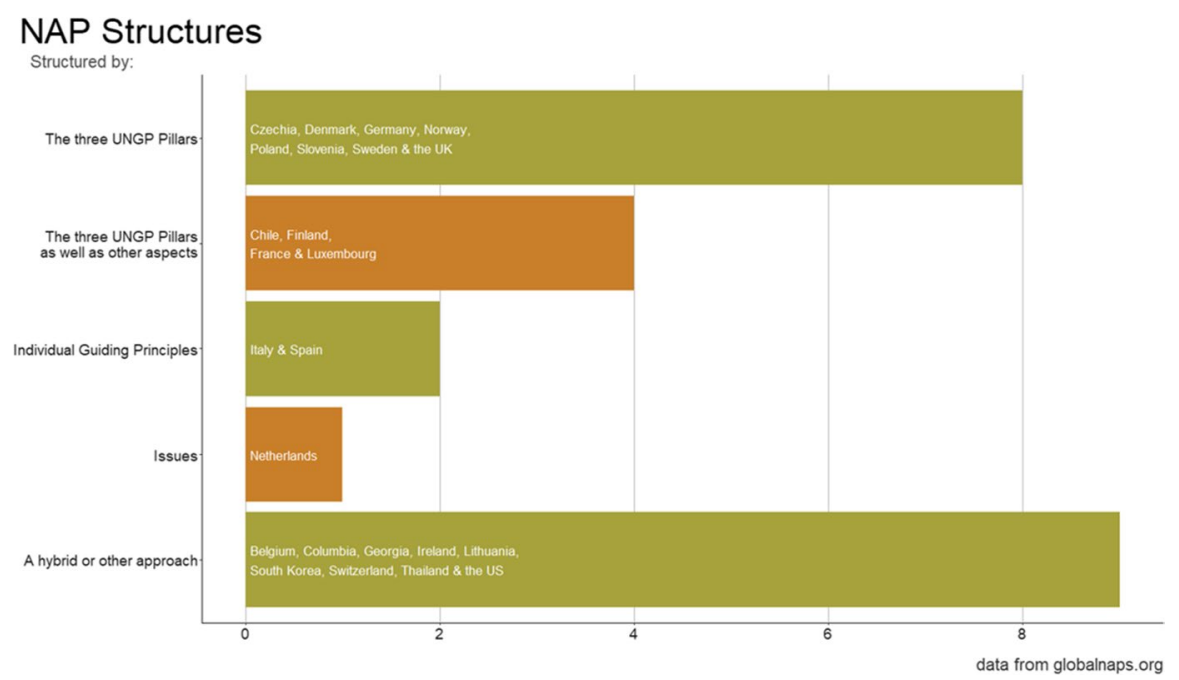

Fig. 4 NAP structures

adopted by the NAP steering committee, was key to orienting next steps in the process.

In Georgia, similarly, a coordination group including representatives from the government's Human Rights Secretariat, an NGO and the NHRI was established to jointly undertake the NBA. Here, three consultations with the civil service, business, and civil society organisations were held. A draft NBA was shared with these entities and their feedback incorporated into the final NBA. Stakeholders in Germany and Georgia hence appear to have participated in problem definition and the identification of policy responses. Yet, this does not seem true of all NBA processes. In Norway, for instance, an NBA was devised "through interviews with officials from various ministries and government institutions" while broad stakeholder involvement not realised. ${ }^{21}$

\section{Implementation, Monitoring and Reporting}

NAP guidance recommends that NAPs should contain measures to monitor and communicate about their implementation. A majority of published NAPs do so: indeed, seventeen states' NAPs commit to producing progress reports and to establishing a committee or forum to monitor NAP implementation. Yet, as Table 4 shows, only eight states have actually produced the promised progress reports (Belgium, Chile, Columbia, Finland, Luxembourg, Netherlands, Sweden and the UK). Furthermore, most NAPs do not identify indicators by which progress towards implementation could be meaningfully measured, milestones or final deadlines for achievement of their stated objectives.

\footnotetext{
21 See: https://globalnaps.org/country/norway/.
} 


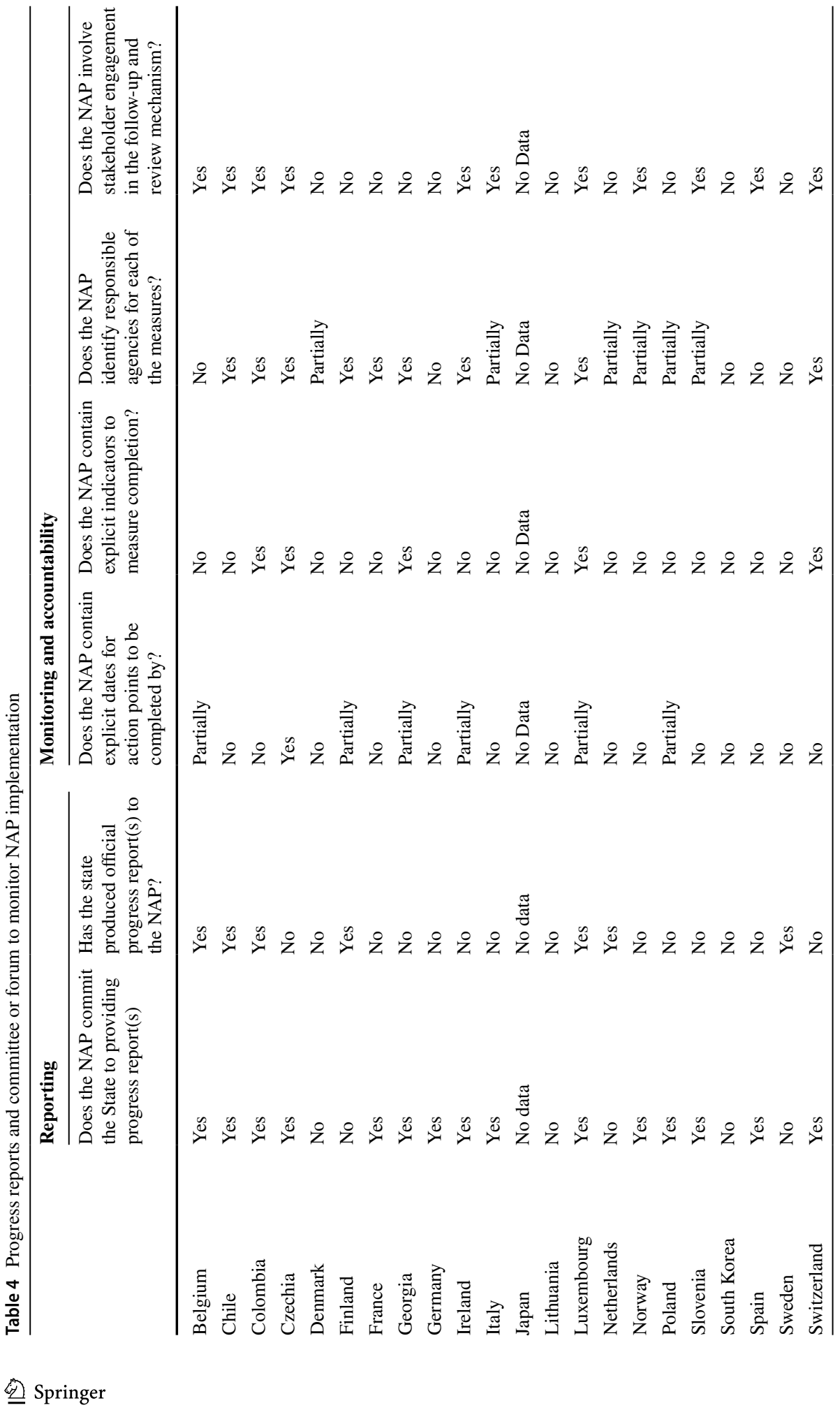




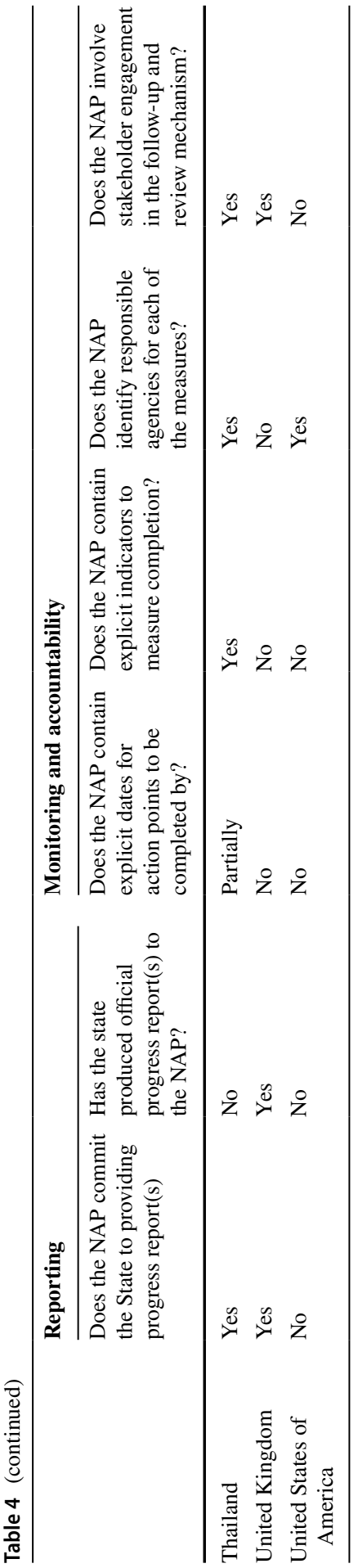


A minority of NAPs do include targets and mechanisms to support monitoring. Germany's NAP included an aim:

"that at least $50 \%$ of all enterprises based in Germany with more than 500 employees will have incorporated the elements of human rights due diligence described in this chapter into their corporate processes by $2020 \ldots$ [if] the target is thus missed, the Federal Government will consider further action, which may culminate in legislative measures" (German Federal Foreign Office, 2016, p. 10).

When it was found in 2020 that only " 13 to 17 percent of the enterprises observed complied with the NAP requirements" (German Federal Foreign Office, 2020), a process was triggered that culminated in the adoption of a new national corporate human rights due diligence law. ${ }^{22}$ Companies covered by the law must identify risks of human rights violations and environmental destruction by direct suppliers and, where relevant, indirect suppliers (Methven O'Brien 2021). Yet, this concrete approach to monitoring, particularly the threat of legislative tied to specific milestones, is unique. As Table 4 shows, albeit twelve NAPs assign responsibility for actions to named entities, six NAPs identify timelines for achieving some or all actions; seven NAPs rely on indicators or dates for completing actions.

In addition, as noted elsewhere, there is a noticeable a tendency for NAPs to recapitulate existing measures, linking these to the UN Framework ex post facto (Augenstein et al. 2018; Ferguson et al., 2018), rather than including UNGPs-inspired measures ex novo.

\section{Revision and Re-evaluation Involving Peer Review}

Both experimentalist governance theory and NAPs guidance emphasise the need for an ongoing cycle of policy revision. Such an approach is observable across a number of states in practice. As shown in Table 1, Italy, Luxembourg, Switzerland and the UK have published revised or updated NAPs; Poland has committed to fully revising its NAP; and the Netherlands seems set to release an updated NAP shortly. Spain's NAP situates itself within a "continuous process", promising an updated version after three years. Belgium's NAP likewise commits to evaluation and possible revision after three years. Czechia's NAP states that it is a "living document" that can be updated and Chile's includes a "roadmap" specifying thirteen issues for consideration in a second version.

As regards peer review, albeit without any formal mandate, various regional and international organisations have convened peer learning events on NAPs in recent years, with wide state participation, in Europe, Asia, Africa and the Americas, as well as inter-regionally. The Council of Europe has established an online platform for information exchange on NAPs and a standard questionnaire for states. Together, these might in principle unearth information needed to facilitate peer review, yet

22 DEUTSCHER BUNDESTAG, 'Gesetzesentwurf der Bundesregierung: Entwurf eines Gesetzes über die Unternehmerischen Sorgfaltspflichten in Lieferketten ', Drucksache 19/28649, 19.04.2021, available at https://dserver.bundestag.de/btd/19/286/1928649.pdf. 
COE states have so far proved somewhat unresponsive to this initiative (Methven O’Brien 2021).

\section{Experimentalist Business and Human Rights Governance: Are NAPs Measuring Up?}

The last section summarised results of our analysis of NAPs processes in twentyfive countries against characteristics derived from recommendations made by NAPs guidance and traits of experimentalist governance as proposed by scholars. ${ }^{23}$ Here, we explore the potential significance of the findings reported and highlight aspects warranting further research.

Our first observation was that stakeholder involvement is widespread across NAPs; generally spans stakeholder categories; and in many cases is supported through the establishment of institutions or structures. In itself, this appears positive and in alignment with experimentalist governance tenets. On the other hand, dedicated measures to give voice to rights-holders at heightened risk of business and human rights abuses were generally lacking. From the perspective of experimentalist governance, especially in the absence of defined legal mandates or the involvement of elected representatives, "democratic legitimacy" depends on participation (de Búrca et al. 2013, p. 785); more particularly, it requires "targeted empowerment of marginalised social groups" (MacDonald and MacDonald 2020, p.536). This study has not revealed whether NAPs open up business and human rights governance in ways that tend to mitigate existing patterns of inclusion and exclusion, or whether they rather reproduce, or even exacerbate, the influence of "self-selecting and usually already powerfully positioned participants" (de Búrca 2010, p. 236). Given the common centring of NAPs on the UN Framework and UNGPs, it may also be that dissenting parties who for whatever reason do not accept this framework as a point of departure, or marginal actors lacking capacity to engage with abstract international human rights norms, are already effectively excluded. What this article has shown, then, is the urgency of investigating and finding ways better to qualify the character of stakeholder participation in NAPs, and measures to promote this, given the extensive role notionally afforded to stakeholder involvement in NAPs development in practice.

Second, and subject to the caveat just noted, it appears that NAPs are being developed on a platform of broad agreement amongst stakeholders around the definition of a regulatory problem encapsulated in the UN Framework and UNGPs. Still, if government, business, civil society actors and others have been prepared

\footnotetext{
23 To recap, for readers' convenience, these we identified earlier as (i) openness to participation of 'stakeholders' in a non-hierarchical process; (ii) articulation of a framework definition of a problem or goals which identifies open-ended objectives to be pursued; (iii) implementation by 'lower-level' actors with knowledge of local conditions and discretion to adapt framework norms to these different contexts" (de Búrca et al. 2014, p.478; de Búrca et al. 2013, p.739; Sabel and Simon 2011, p.55); (iv) continuous feedback and "mutual monitoring and peer review, serving an accountability function (de Búrca et al. 2013, p.742); v) periodic revision and re-evaluation of goals and practices in light of peer review and shared purposes" (de Búrca et al. 2014, p.478).
} 
prima facie to engage in discussion of the application of specific international human rights standards to the national setting, the depth of agreement, and its motivation, remain unclear. Relatedly, this study has not disclosed the extent of conflicts between actors in a given NAP process, or across NAPs, over interpretation of norms, the identification or selection of priorities. Deeper-reaching individual case studies and comparative studies should be undertaken to supplement our findings in this regard.

At the same time, there is a relatively high degree of variation in the structure and approach of NAPs, with few favouring, for instance, the transparent UNGP-byUNGP approach advocated by guidance. Such inconsistencies are a challenge for certain forms of accountability: NAPs cannot be meaningfully compared, on this basis, by applying simple binary parameters. Yet such divergences across NAPs' content, and underinclusivity, are actually expected by experimentalist governance theory, which foresees a lack of agreement between governments on precise approaches or solutions, value differences, and thus a persisting role for the exercise of regulatory discretion by local actors. This indeed forms part of the rationale for scrutiny via peer-review, considered further below.

Thirdly, its learning potential is a key virtue of experimentalist governance according to its proponents. Rather than wedding actors to one set of policies for all time, experimentalist governance processes should be an engine for their collaborative critique, ongoing reformulation and revision. A commitment to revision reflects the inherent "uncertainty" of the problem to be addressed and where participants are conscious of the "limits on their foresight, and of the possible fallibility of initially preferred solutions" (de Búrca et al. 2014, p.479). Experimentalist governance regimes "must enable participants to learn continuously to redefine the problems they face" (de Búrca et al. 2013, p.740) as well as revising the "goals, metrics and procedures" that have been established initially (Sabel and Zeitlin 2008, p.272).

The progressive learning dimension of revision however has obvious preconditions: amongst them are reliable data on regulatory responses and outcomes, as well as openness of governments to update instruments. In this area, published NAPs do both well and poorly. NBAs, which may be viewed as a proxy for local knowledge on the business and human rights state of play, and a ground zero against which to measure progress over time, are sparse. Granular national policy commitments linked to numerical or even qualitative targets are few and far between. Given this, informed reflection on how effective specific policy approaches on business and human rights are will be hard. Peer review at regional or international level will have little to "bite" on beyond anecdotal or case reports which, while not without significance, are an incomplete basis for evaluating policy effectiveness (Ferguson et al. 2018, p.10). Overall, without a more extensive infrastructure of targets, benchmarks, indicators and reporting formats, this and their concomitant capacity to contribute to policy "learning" will remain weak.

This carries implications for our findings, fourthly, relating to revision of business and human rights NAPs. To recall, a majority of NAPs commit to revision, while a smaller number have already been revised. On one hand, then, our data suggests that states are well-inclined to revision and updating of NAPs, in accordance with experimentalist governance tenets. On the other hand, lacking the institutional 
and informational apparatus needed to evaluate progress and effectiveness of business and human rights policy measures, it is unclear how second- or subsequent NAPs can embody informed reflection or "policy learning". As Ferguson et al. report, though the UK produced a revised NAP following stakeholder consultation, "its contents simply repeated much of the original NAP" and contained "very few forward elements and... no objectives to monitor" (2018, p.9).

In experimentalist theory, "peer review of the diverse experience of the actors attempting to realise the desired outcomes" is an essential component of learning (de Búrca et al. 2014, p.479). Uncertainties associated with a broad problem definition, combined with the likelihood of value conflicts within and across states, mean that policy choices will vary locally, and legitimately so. Discursive evaluation, structured according to commonly defined parameters, will be more appropriate in this setting, than imposing specific legislative forms or numerical goals and this is the end to which peer review should be directed. Peer dialogues around business and human rights NAPs have been a somewhat regular occurrence over recent years. This is welcome. Nevertheless, peer events until now have lacked the character of peer review, as practiced in other institutional settings, for instance the European Union's Open Method of Coordination, the United Nations Universal Periodic Review, or in the Organisation for Economic Cooperation and Development. Presentations by states on their NAPs experiences cannot substitute for structured scrutiny by peers and stakeholders on the basis of a selection of salient parameters, as recently highlighted by the European Council (EC 2020).

Finally, this study permits some reflections on the value of experimentalist governance theory and its application in the human rights domain. According to de Burca (2017, p.277), rather than operating as the ineffective, top-down hierarchical process characterised by its critics, human rights regimes, in reality, operate in a more interactive manner that resembles the core architecture of experimentalist governance. Moreover, she maintains that "human rights regimes... function at their best as dynamic, participatory, and iterative systems". Our study lends support to de Burca's (2017) observation, by highlighting the iterative and participatory processes that generally underpin NAP processes. Nevertheless, our study also highlights some of the limitations of operationalising experimentalist governance in an empirical setting; in particular, if one wants to assess the effectiveness of human rights experimentalist governance - this would require in-depth, longitudinal case study analysis that would ideally incorporate an element of qualitative enquiry with stakeholders that have engaged in participatory NAP processes.

\section{Conclusion}

In tandem with their broadening uptake by states, NAPs have attracted growing interest from business and human rights scholars. On one side, concerns have been raised that NAPs are used by governments as a pretext for avoiding 'hard' regulation (Cantu Rivera 2019) or substantive standards (Jensen, Lagoutte and Lorion 2019), or even that they embody a tendency towards "neoliberal bureaucratisation" of human rights (Hibou 2015, cited by Lorion 2019, p.241). On the other side, it 
has been suggested, NAPs might "trigger government commitments to implement business and human rights standards, so delivering better 'vertical' alignment of national laws, policies, and institutional practices with international commitments" (Methven O'Brien et al. 2016). In addition, they might encourage the "cross-government participation needed to secure 'horizontal' policy coherence" and, if they promote "transparency, inclusion, participation, and non-discrimination... [also] empower rights-holders and generate space for dialogue and greater mutual understanding between stakeholders" (ibid, p.121). If, moreover, NAPs "include clear and evidence-based targets, milestones, and indicators, they ought additionally to provide a basis for holding governments to account and over time doing so on a comparative basis with other countries" (ibid., p.121).

NAPs and NAPs processes may be regulatory in themselves, exerting effects on a range of actors. However, they are also potentially pre-regulatory, inasmuch as they may lead to or create conditions encouraging the adoption of substantive policies, legislation or other measures, or indeed of other pre-regulatory networks or dialogue mechanisms. Given this, pronouncing on the ultimate consequences of business and human rights NAPs for effective enjoyment of human rights seems premature (cf. Cantu Rivera 2019). On the other hand, the character of NAPs processes can still be meaningfully assessed. Accordingly, this article has sought to evaluate NAPs processes from the standpoint of experimentalist governance theory. Our analysis has investigated how NAPs processes are unfolding and whether they reflect the character and role afforded to local implementation mechanisms hypothesised by experimentalist governance theory and as observed in other human rights and governance contexts.

This study has discerned a prima facie resemblance between NAPs and local implementation devices premised by the institutional architecture of experimentalist governance (Goldstein and Ansell 2018, p.243). Consequently, NAPs may have potential to provide the basis for an institutional framework to address the complex problems that emerge in the business and human rights context and as a basis for "dealing with the failure of traditional problem-solving strategies and multilevel cooperation in decision making" (Armeni 2015, p.884). Despite such positive features, our analysis also however points to variations across NAPs and a number of general weaknesses. In particular, NAPs need to institutionalise inclusion of constituencies at risk of marginalisation and discrimination; they need to rest on stronger data at the outset and gathered and published over time on a consistent if not universally prescribed basis, and they need to be scrutinised via stronger and more routinised processes of peer review.

Nevertheless, the weaknesses of NAPs identified here do not seem fatal or to signify a lack of traction of international business and human rights norms, even those of a soft law nature. Rather, highlighting the emergence of relatively sophisticated governance architectures in the context of NAPs practice, along with the limitations and preconditions that may attach to their effectiveness, our analysis draws attention to the potential for further development of NAPs processes in the future, which should be informed by further research in the areas we have indicated above. 
Acknowledgements The authors thank Colbyn MacPhail and Lars Heidtmann for research assistance. They also acknowledge data extracted from globalnaps.org and provided by Daniel Morris and Lukas Bogner of the Danish Institute for Human Rights.

Funding Research for this article was partly funded by Danida, "Realising the SDGS: The role of responsible business".

Open Access This article is licensed under a Creative Commons Attribution 4.0 International License, which permits use, sharing, adaptation, distribution and reproduction in any medium or format, as long as you give appropriate credit to the original author(s) and the source, provide a link to the Creative Commons licence, and indicate if changes were made. The images or other third party material in this article are included in the article's Creative Commons licence, unless indicated otherwise in a credit line to the material. If material is not included in the article's Creative Commons licence and your intended use is not permitted by statutory regulation or exceeds the permitted use, you will need to obtain permission directly from the copyright holder. To view a copy of this licence, visit http://creativecommons.org/licen ses/by/4.0/.

\section{References}

Abbott, K.W. (2017) Orchestrating experimentation in non-state environmental commitments, Environmental Politics, 26:4, 738-763.

Armeni, C. (2015) Global experimentalist governance, institutional law and climate change technologies. International and Comparative Law Quarterly, 64: 875-904

Augenstein, D. Dawson, M. \& Thielbörger, P. (2018) The UNGPs in the European Union: the open coordination of business and human rights. Business and Human Rights Journal, 3(1): 1-22

Bar-Siman-Tov, I. (2016). Temporary Legislation, Better Regulation and Experimentalist Governance: An Empirical Study. Regulation and Governance, 12:192-219

Barcevicius, E., Weishaupt, T., \& Zeitlin, J. (eds.) (2014) Assessing the open method of coordination institutional design and national influence of EU social policy coordination. Palgrave Macmillan

Berman, P. S. (2020) Understanding Global Legal Pluralism: From Local to Global, from Descriptive to Normative in P.S. Berman (ed) The Oxford Handbook of Global Legal Pluralism (pp. 1-36).

Birchall, D. (2021). Corporate Power over Human Rights: An Analytical Framework. Business and Human Rights Journal, 6(1), 42-66

Black, J. (2002) Critical Reflections on Regulation. Australian Journal of Legal Philosophy 27: 1-35.

Black, J. (2008), Constructing and contesting legitimacy and accountability in polycentric regulatory regimes. Regulation and Governance, 2: 137-164.

Braithwaite, J. \& Drahos, P. (2000) Global Business Regulation. OUP.

Broberg, M., \& Sano, H.O. (2018) Strengths and weaknesses in a human rights-based approach to international development - an analysis of a rights-based approach to development assistance based on practical experiences. The International Journal of Human Rights, 22(5): 664-680

Cantú Rivera, H. (2019), National Action Plans on Business and Human rights: Progress or Mirage? Business and Human Rights Journal, 4(2): 213-237.

Chalabi, A. (2018a) National human rights action planning. OUP.

Chalabi, A. (2018b) Added values of national human rights action planning for the UK in the Age of Brexit. UK Constitutional Law Association. https://ukconstitutionallaw.org/2018/04/30/azadehchalabi-added-values-of-national-human-rights-action-planning-for-the-uk-in-the-age-of-brexit/. Accessed 24 August 2020

Chalabi, A. (2014) The nature and scope of states' obligation to adopt a national human rights action plan. The International Journal of Human Rights, 18: 391-413.

Chimhowu, A., Hulme, D., \& Munro, L. (2019) The 'new' national development planning and global development goals: processes and partnerships. World Development, 120: 76-89.

Council of the European Union (2012) EU Strategic Framework on Human Rights and Democracy. https://www.consilium.europa.eu/uedocs/cms_data/docs/pressdata/en/foraff/131181.pdf. Accessed: 24 August 2020 
Council of the European Union (2015) Action Plan on Human Rights and Democracy 2015-2019.https:// ec.europa.eu/anti-traffickin`g/sites/antitrafficking/files/action-plan-on-human-rights-and-democracy-2015-2019_en.pdf Accessed: 24 August 2020

Council of the European Union (2020) Conclusions on Human Rights and Decent Work in Global Supply Chains of 2020, https://www.consilium.europa.eu/media/46999/st13512-en20.pdf Accessed 2 December 2020.

Council of Europe, Steering Committee for Human Rights, Drafting Group on Human Rights and Business (2014) Draft recommendation of the committee of ministers to member states on human rights and business. http://www.coe.int/t/dghl/standardsetting/hrpolicy/Other_Committees/HR_ and_Business/Documents/CDDH-CORP\%20Draft\%20Recommendation\%20Human\%20Rights\% 20and\%20Business\%20Final\%20ENG.pdf. Accessed 14 August 2020

Dawson, M. (2010) Transforming into what? new governance in the EU and the "managerial sensibility" in modern law. Wis. L. Rev., 2010(1): 389-440.

Dawson, M. (2011) New governance and the transformation of European law: coordinating EU social law and policy. Cambridge University Press.

de Búrca, G. (2010) New governance and Experimentalism: An introduction. Wisconsin Law Review, 2: 227-238

de Búrca, G. (2017). Human Rights Experimentalism. American Journal of International Law, 111(2): 277-316.

de Búrca G, \& Scott, J. (2006) Introduction. In: G de Búrca, \& J. Scott (eds) New Governance, Law and Constitutionalism, in Law and New Governance in the EU and the US. Hart Publishing.

de Búrca, G., Keohane, R., \& Sabel C (2013) New modes of pluralist global governance. New York University Journal of International Law and Politics, 45: 723-786

de Búrca, G., Keohane, R., \& Sabel, C. (2014) Global experimentalist governance. British Journal of Political Science, 44(3): 477-486

de Felice, D., \& Graf, A. (2015). The potential of national action plans to implement human rights norms: An early assessment with respect to the UN guiding principles on business and human rights. Journal of Human Rights Practice, 7(1): 40-71.

DIHR (2020) National Action Plans on Business and Human Rights https://globalnaps.org Accessed: 24 August 2020

DIHR (2020), National Action Plans on Business and Human Rights, Resources. https://globalnaps.org/ resources/ Accessed: 24 August 2020

DIHR/ICAR (2014) National Action Plan on business and human rights Toolkit

DIHR/ICAR (2017) National Action Plan on business and human rights Toolkit https://www.human rights.dk/publications/national-action-plans-business-human-rights-toolkit-2017-edition Accessed: 24 August 2020

Dorf, M., \& Sabel, C. (1998) A Constitution of Democratic Experimentalism Columbia Law Review, 98(2): 267-473.

Dufoix, S. (2012) La Dispersion. Une histoire des usages du mot diaspora. Éditions Amsterdam.

European Commission (2020) "National GPP Action Plans" https://ec.europa.eu/environment/gpp/pdf/ 200311_GPP_NAPs_March_2020.pdf Accessed: 24 August 2020

European Commission (2011) A Renewed EU Strategy 2011-14 for Corporate Social Responsibility. COM 681. http://eur-lex.europa.eu/LexUriServ/LexUriServ.do?uri=COM:2011:0681:FIN:en:PDF Accessed: 14 August 2020

European Group of National Human Rights Institutions (2012) Implementing the UN Guiding Principles on Business and Human Rights: Discussion paper on National Action Plans for EU Member States http://businesshumanrights.org/en/pdf-implementing-the-un-guiding-principleson-business-and-human-rights-discussion-paper-onnational-implementation-plans-for-eu-member-states. Accessed: 24 August 2020

European Network of National Human Rights Institutions (2020) Human rights- based approach http://ennhri.org/about-nhris/human-rights-based-approach/ . Accessed: 10 November 2020

European Union Agency for Fundamental Rights (2014) https://fra.europa.eu/en/publication/2015/ mapping-child-protection-systems-eu/national-policy. Accessed: 10 November 2020

Ferguson J, Methven O’Brien C, McVey M, Morris D (2018) Securing sustainable and accountable business in Europe: the role of National Action Plans. https://mk0globalnapshvllfq4.kinstacdn. com/wp-content/uploads/2019/01/scotlandnap_accountability_workshop_report.pdf. Accessed: 24 August 2020 
Finnemore M., \& Sikkink K. (1998) International norm dynamics and political change International Organization, 52: 887-917.

German Federal Foreign Office (2020) Monitoring the National Action Plan for Business and Human Rights (NAP).https://www.auswaertiges-amt.de/en/aussenpolitik/themen/aussenwirtschaft/wirts chaft-und-menschenrechte/monitoring-nap/2131054. Accessed: 20 December 2020

Goldstein, G., \& Ansell, C. (2018) Experimentalist governance in global public health: The case of UNAIDs. Arizona Journal of International \& Comparative Law, 35(2):219-256

Guy Peters, B. (2011) Steering, rowing, drifting or sinking? Changing patterns of governance. Urban Research \& Practice, 4(1): 5-12.

Hampton, D. (2019). Modern Slavery in Global Supply Chains: Can National Action Plans on Business and Human Rights Close the Governance Gap? Business and Human Rights Journal, 4(2): 239-263

Hooghe, L., Marks, G. (2001) Multi-level governance and European integration. Rowman \& Littlefield.

James, P., \& Steger, M. (2014) A genealogy of 'Globalization': The career of a concept. Globalizations, 11(4): 417-434.

Kenner, J., \& Peake, K. (2017) The Bangladesh Sustainability Compact: An effective exercise of global experimentalist EU governance. Cambridge Yearbook of European Legal Studies, 19: 86-115.

Keohane, R., \& Victor, D. (2011) The regime complex for climate change. Perspectives on Politics, 9: 7-23

Levi-Faur, D. (2012). 'From "Big Government" to "Big Governance"?' in David Levi-Faur (ed), The Oxford Handbook of Governance (Oxford University Press 2012).

Lawton, S. (2020) German labour ministry ramps up pressure for supply chain law. https://www.eurac tiv.com/section/economy-jobs/news/german-labour-ministry-ramps-up-pressure-for-supply-chainlaw/. Accessed: 20 December 2020

Lorion, S. (2019) A model for national human rights systems? new governance and the convention on the rights of persons with disabilities. Nordic Journal of Human Rights, 37(3); 234-25.

MacDonald, T., \& MacDonald, K. (2020) Towards a 'pluralist' world order: creative agency and legitimacy in global institutions. European Journal of International Relations, 26(2): 518-544.

Methven O'Brien, C., Mehra, A., Blackwell, S., \& Poulsen-Hansen C.B. (2016) National action plans: Current status and future prospects for a new business and human rights governance tool. Business and Human Rights Journal, 1(1): 117-126.

Methven O'Brien, C., \& Ford, J. (2019) Business and human rights: from domestic institutionalisation to transnational governance and back again. Nordic Journal of Human Rights, 37(3): 216-233.

Morris, D., Bogner, L., Daubigeon, L., Blake, A., \& Wrzoncki, E. (2018) National action plans on business and human rights: an analysis of plans from 2013 - 2018. The Danish Institute for Human Rights. https://www.humanrights.dk/sites/humanrights.dk/files/media/document/NAP\%20analysis. pdf. Accessed: 24 August 2020

Nance, M and Cottrell, M. (2014). A turn toward experimentalism? Rethinking security and governance in the twenty-first century. Review of International Studies, 40(2): 277-301.

Nicolson, C., Blake, A., Ross, J., Morris D (2018) Workshop Report Securing Sustainable and Accountable Business in Europe: The role of National Action Plans on Business and Human Rights (NAPs) Edinburgh, 5th June 2018 https://mk0globalnapshvllfq4.kinstacdn.com/wp-content/uploads/2019/ 01/scotland-nap_accountability_workshop_report.pdf. Accessed 2 December 2020.

OAS (Organization of American States) (2014) Promotion and protection of human rights in business. GA Res 2840 (XLIV-O/14)

OAS (Organization of American States) (2016) Promotion and protection of human rights. AG/RES.2887 (XLVI-O/16)

OECD (2017) National action plans on business and human rights to enable policy coherence for responsible business conduct. https://mneguidelines.oecd.org/NAP-to-enable-policy-coherence-for-RBC. pdf Accessed: 24 August 2020

Osborne, D., \& Gaebler, T. (1992) Reinventing government: how the entrepreneurial spirit is transforming the public sector. Basic Book.

Panke, D. , \& Haubrich Seco, M. (2016) "EU and supranational governance" In: Jacob Torfing \& Chris Ansell (Ed) Handbook on Theories of Governance, p.499-51. Edward Elgar: Cheltenham.

PeaceWomen (2020), https://www.peacewomen.org/member-states_Accessed 24 August 2020

Ruggie, J. (2002) The Theory and Practice of Learning Networks. Journal of Corporate Citizenship, 5: 27-36. 
Ruggie, J. (2013) Just business: multinational corporations and human rights. W.W. Norton \& Co.

Ruggie, J. (2014) Global governance and "new governance theory": lessons from business and human hights. Global Governance, 20(1): 5-17.

Ruggie, J. (2020) The social construction of the UN Guiding Principles on Busines and Human Rights. In: S. Deva, \& D. Birchall (eds) Research Handbook on Human Rights and Business. Edward Elgar, Massachusetts, p.63-88.

Sabel, C., \& Zeitlin, J. (2008) Learning from difference: The new architecture of experimentalist governance in the EU. European Law Journal, 14(3): 271-327

Sabel, C., \& Zeitlin, J. (2012) Experimentalist Governance. In: D. Levi-Faur (ed) The Oxford Handbook of Governance. Oxford University Press, pp.169-184.

Sen, A., \& Anand, S. (1994) Human Development Index: Methodology and Measurement. Human Development Report Office Occasional Paper 12.

Soh, C., \& Nam, S. (2018). Business and Human Rights Case Study of Korean Companies Operating Overseas: Challenges and a New National Action Plan. Human Rights Quarterly 40(2), 287-316

Teubner, G. (1983). Substantive and Reflexive Elements in Modern Law. Law and Society Review, 17: 239.

Teubner, G. (1997), Global Bukowina: Legal Pluralism in World Society. In: G. Teubner (ed) Global Law without a State, pp. 3-31. Aldershot.

Tuangratananon, T. Sangay Wangmo, S., Widanapathirana, N., Pongutta, S., Viriyathorn, S., Patcharanarumol, W., Thin, K., Nagpal, S., Nuevo, C. E. L., Padmawati, R. S., Puyat-Murga, M. E., Trisnantoro, L., Wangmo, K., Wellappuli, N., Hoang Thi, P., Khuong Anh, T., Zangmo, T., \& Tangcharoensathien, V. (2019) National action plans on non-communicable diseases Implementation of national action plans on noncommunicable diseases, Bhutan, Cambodia, Indonesia, Philippines, Sri Lanka, Thailand and Vietnam. Bulletin of the World Health Organization, 97(2): 73-168.

UN Sustainable Development Group/UN SDG Human Rights Working Group (2003) The Human Rights Based Approach to Development Cooperation Towards a Common Understanding Among UN Agencies. https://unsdg.un.org/resources/human-rights-based-approach-development-cooperationtowards-common-understanding-among-un Accessed 2 December 2020.

UN Human Rights Council (2011) Guiding Principles on Business and Human Rights: Implementing the United Nations "Protect, Respect and Remedy" Framework A/HRC/17/31 https://www.ohchr.org/ documents/publications/guidingprinciplesbusinesshr_en.pdf. Accessed: 24 Aug 2020

UN Human Rights Council (2008) Report of the Special Representative of the Secretary-General on the Issue of Human Rights and Transnational Corporations and Other Business Enterprises: Protect, Respect, Remedy: A Framework for Business and Human Rights. UN Doc A/HRC/8/5 https:// documents-dds-ny.un.org/doc/UNDOC/GEN/G08/128/61/PDF/G0812861.pdf?OpenElement Accessed: 24 August 2020

UN Human Rights Council (2012) Report of the Working Group on the Issue of Human Rights and Transnational Corporations and Other Business Enterprises. UN Doc A/HRC/20/29 https://www. ohchr.org/Documents/Issues/Business/A.HRC.20.29_en.pdf. Accessed: 24 Aug 2020

UN Human Rights Council (2014) Human Rights and Transnational Corporations and Other Business Enterprises. UN Doc A/HRC/RES/26/22. http://daccess-dds-ny.un.org/doc/UNDOC/GEN/G14/ 083/82/PDF/G1408382.pdf?OpenElement. Accessed: 20 August 2020

UN OHCHR (Office of the High Commissioner for Human Rights) (1993) Vienna Declaration and Programme of Action. https://www.ohchr.org/Documents/ProfessionalInterest/vienna.pdf. Accessed: 24 August 2020

UN OHCHR (n.d.) 1st UN Pacific Forum on Business and Human Rights. https://www.ohchr.org/EN/ Issues/Business/Pages/2020UN-pacific-forum.aspx. Accessed: 2 December 2020.

UN Working Group on Business and Human Rights (2012) Report of the Working Group on the Issue of Human Rights and Transnational Corporations and Other Business Enterprises', A/HRC/20/29 (10 April 2012).

UN Working Group on Business and Human Rights (2014) Guidance on National Action Plans on Business and Human Rights. https://www.ohchr.org/Documents/Issues/Business/UNWG_\%20NAP Guidance.pdf Accessed: 24 August 2020

UN Working Group on Business and Human Rights (2016) Guidance on National Action Plans on Business and Human Rights. https://www.ohchr.org/EN/Issues/Business/Pages/NationalActionPlans. aspx. Accessed: 24 August 2020

Weber, M. (1978) Economy and society: an outline of interpretive sociology. University of California Press. 
Wolfsteller, R. (2020) Out of sync: The failed translation of international human rights in the creation of the UK Human Rights Act, Journal of Human Rights, 19:3, 325-343

World Bank (1983) World Development Report. OUP, New York, cited by Chimhowu A, Hulme D, Munro L (2019) The 'New' national development planning and global development goals: Processes and partnerships. World Development 120:76-89

Methven O'Brien, C., Mehra, A., Blackwell, S., \& Poulsen-Hansen, C. B. (2016). National action plans: current status and future prospects for a new business and human rights governance tool. Business and Human Rights Journal, 1(1), 117-126. https://doi.org/10.1017/bhj.2015.14

Methven O'Brien, C. (2019). Experimentalist global governance and the case for a framework convention based on the UN guiding principles on business and human rights. In M. Mullen (Ed.), Navigating a new era of business and human rights: Challenges and Opportunities under the UNGPs (pp. 204-213). Article 30. https://article30.org/wpcontent/uploads/2019/08/a_new_era.pdf

Fung, A., \& Wright, E.O. (2003). Deepening democracy: Institutional innovations in empowered participatory governance. London: Verso

Methven O'Brien, C. (2021). 'Business and Human Rights in Europe 2011-2021: A Decade in Review', in Czech, P., Heschl, L., Lukas, K., Nowak, M., \& Oberleitner, G. European Yearbook of Human Rights 2021. Intersentia.

de Sousa Santos, B. (1995). Toward a new legal common sense. Law, globalization, and emancipation. London: Butterworths, 2002

Dewey, J. (1927). The public and its problems. Holt.

Goldsmith, J., \& Posner, E. (2005) The Limits of International Law. Oxford University Press Hathaway, Oona . 2002. Do human rights treaties make a difference? Yale Law Journal 111:1935-2042.

Hathaway, O. (2007). Why Do Countries Commit to Human Rights Treaties? The Journal of Conflict Resolution, 51(4), 588-621.

Moyn, S. (2012). The Last Utopia: Human Rights in History. Cambridge, Mass

Neumayer E. (2005). Do International Human Rights Treaties Improve Respect for Human Rights? Journal of Conflict Resolution, 49(6):925-953. https://doi.org/10.1177/0022002705281667.

Posner, E. (2014). The Twilight of Human Rights Law. Oxford University Press.

Sabel, C., F. \& Simon W. H. (2011). Minimalism and experimentalism in the administrative State. Geo LJ, 100(1), 53-94.

Schaffer, K., J. (2012). Deliberative democracy in transnational governance: problems of legitimacy, agency, and representation (August 14, 2012). Available at SSRN. http://doi.org/10.2139/ ssrn.2189357.

Publisher's note Springer Nature remains neutral with regard to jurisdictional claims in published maps and institutional affiliations.

\section{Authors and Affiliations}

\section{Claire Methven $\mathrm{O}^{\prime}$ Brien $^{1} \cdot$ John Ferguson ${ }^{2}\left(\mathbb{D} \cdot\right.$ Marisa McVey $^{2}$}

John Ferguson

jf60@st-andrews.ac.uk

Claire Methven O’Brien

cobrien001@dundee.ac.uk

1 School of Law, University of Dundee, Scrymgeour Building Dundee, Dundee DD1 4HN, UK

2 School of ManagementUniversity of St Andrews, The Gateway North Haugh, St Andrews KY16 9RJ, UK 